\section{"The love of letters half preserves the past" 1}

Jerome McGann, Byron and Romanticism (Cambridge: Cambridge UP, 2002)

Jerome McGann, with his two early books, Fiery Dust: Byron's Poetic Development (1968), Don Juan in Context (1976), and a number of independent articles, has been undoubtedly the most important force behind the renewal of critical interest in Byron. In 1971, with McGann's important contribution, the Byron Society was re-founded (it had operated between 1868 and 1936) which launched The Byron Journal in 1973. Byron's Letters and Journals were re-edited by Leslie A. Marchand (1973-1982, in 13 volumes), and from 1980 to 1992 McGann's own edition of The Complete Poetical Works (7 volumes) was published. These publications speak eloquently for the authority with which McGann can pronounce on issues concerning Byron and Romanticism. His most recent collection of critical essays, Byron and Romanticism, contains papers which were published originally between 1974 and 2001, and promises thus to be a reflection of the greatest part of his carrier.
What had been the problem with Byron, why did he disappear from the field of studies for the better half of the twentieth century? McGann quotes Wellek's classic (1949) definition of Romanticism: "Imagination for the view of poetry, nature for the view of the world, and symbol and myth for poetic style" (236). Not one of these criteria seems applicable to Byron. " 'Imagination' is not Byron's view of the sources of poetry, 'nature' is hardly his 'view of the world' (Byron is a distinctly cosmopolitan writer), and his style is predominantly rhetorical and conversational rather than symbolic or mythic" (238). Most studies in this book revolve around these problems, trying to describe Byron's relation to the authors we still regard, in McGann's judgement, as the centre of Romanticism, i.e. Wordsworth and Coleridge.

The most important study in this respect seems to be the comparative analysis of "Byron and Wordsworth." Byron's attitude to Wordsworth can, it turns out, be summarised as a (mostly) respectful refusal. McGann examines in detail how Byron keeps evoking typically Wordsworthian themes (a wanderer alone in nature, meeting one of those simple people who live close to nature, the soul's attempt to overcome its losses, etc.) and reinterpreting or parodying 
them. Where Wordsworth is "meditative and conceptual," Byron is "energetic and existential" (176). For Wordsworth nature has "ample power / To chasten and subdue," and the soul can be totally absorbed in that "something far more deeply interfused," for Byron, however, (as he writes in his "Alpine Journal") "the crashing of the Avalanche - nor the torrent - the mountain - the Glacier - the Forest - nor the Cloud - have for one moment - lightened the weight upon my heart - nor enabled me to lose my own wretched identity in the Majesty \& the Power and the Glory - around - above - $\&$ beneath me" (179).

From the many connections and differences that McGann discusses, the most important, to which many other essays in the collection return, is Byron's relation to Wordsworthian "sincerity." Critics from Byron's first publications have registered an un- . easiness about his "efforts to control and manipulate his audience" (118). Which means that his writing is openly rhetorical, it directly addresses its audience, and it also engages with the particularities of, for instance, current political issues or his own (not in the least) private life. These are the problems that McGann finds most interesting both theoretically and with regard to the practice of criticism, editing or teaching of this kind of poetry.

First, to say that Byron's writing is rhetorical is not to say that the poetics of "sincerity" could in any way transcend rhetoric. On the contrary, it is a convention, involving more or less clearly definable rhetorical strategies: "(1) a detailed presentation of a concrete immediate context for the poetical text (epitomized in the famous subtitle of Wordsworth's "Tintern Abbey"); (2) the construction of a poetic reverie, as if the reader were 'overhearing' the poet musing ... aloud." (287) In other words, "Byron's poetry argued that 'sincerity' for the poet has to be a convention, an artifice of language" (96). Moreover, in his own work he manages to be both personal ("sincere") and rhetorical. The advantages are twofold. On the one hand, "Byron agrees to use himself up - to ... treat himself as a thing to be coldly anatomized and observed. The reward? Simply increased self-awareness" (99). On the other hand, Byron, who "placed himself at the centre of his work and made a Brechtian theatre of his Romantic self-expression and sincerity" (97), can hinder his readers from willingly suspending their disbeliefs, and achieve the same "psychic coldness" and "indifference of consciousness" that "Baudelaire, 
Nietzsche, and Flaubert valued in Byron's writing" (161).

The second problem has to do with McGann's overall relationship to poetry. In his view, poetry stands (using the Aristotelian terminology) halfway between history and philosophy, which, for McGann, is to say that it cannot and must not be separated from those facts, material, social, biographical and bibliographical, that are active in the shaping of the work (227). "The [historical] method ... attempts to specify the concrete and particular forms in which certain human events [one of which is poetry] constituted themselves" (211). It is this attempt to unchain the work of literature from these "concrete and particular forms" that McGann called The Romantic Ideology (1983). The theoretical representatives of this ideology he calls variously Kant, Coleridge, New Criticism, and even Gadamer.

"Poems are first of all acts of representation; as such, they can only be read when the entire facticity of those acts is raised into consciousness. The acts are begun and carried forward in specific socio-historical circumstances, and the poetical investments in those circumstances - what poems give and receive back - are not merely recorded in the poems, they are executed in them." Thus McGann argued in his 1989 Towards a Literature of Knowledge (131). The final aim of this methodology is very clear: McGann is trying to regain the critical potential in literary works, in the social, political sense of the word. He quotes Adorno to point out that "We move towards a literature of knowledge when we understand that 'Truth is the antithesis of existing society' " (Towards a Literature of Knowledge, 130).

The element of the reconstruction of a poem's "facticities" that McGann puts most elaborately forward is the treatment of bibliographical information. To the question "What difference do the circumstances of publication make to the interpretation of a literary work?" (the title of a 1991 essay in Byron and Romanticism) McGann has already given a lot of attention. The project (in which he naturally relies on his own editorial experience ${ }^{2}$ ) can be summarized as an attempt at eliminating the distance between the practices of textual and literary criticism. The literary critic, on the one hand, must not regard a book, a text (not even the best critical edition) as something fixed, or final. On the contrary, it is to be seen as the product of specific people, working under specific circumstances, that is, the interpretation of the work has to entail a reconstruc- 
tion of all the details of its bibliography; "textual history" and "reception history" are very strongly interrelated (232). Textual critics, on the other hand, have to discard the supposition that they are working only with "positive" data; textual studies and editorial work always involve an interpretative element as well. He discusses, as an example, a plate from Blake's Jerusalem, which Blake himself mutilated very severely; it is not enough, McGann claims, to try to recover the erased passages, "we will want to ground our readings in the mutilated text, rather than the editorially corrected text" (80).

To recover the "facticities" concerned in the literary work is important for McGann from another respect as well. "The historical particularit[ies] ... have to be clearly specified in the act of criticism if that act is to proceed dialectically, i.e., if that act is not simply to project upon 'the work' its own conceptual interests" (213). In these essays, the emphasis on this issue is somewhat diminished, but from, for instance, The Romantic Ideology it is very clear that for McGann the "conceptual interests" are ideological in nature. There he elaborated a dialectical framework, in which the critic should attempt to reconstruct the original context of the work ("I make myself a picture of great detail" he quotes from one of his favourites, Milman Parry) to be able to leave behind the prejudices of his own age as much as possible, but also to cast a critical eye on his own age from the perspective of the work of the past. In other words, the critic achieves his/her relative freedom from ideological prejudices by a constant mental movement between past and present.

The most important aim of The Romantic Ideology was first, to attack "Wellek's position" which "flattens out the rough terrain of the cultural formation(s) we call Romanticism; and second [to prove], that Wellek's position fails to map the phenomena comprehensively because it is a specialized theoretical view derived from a Kantian/Coleridgean line of thought" (237). From the critical reception of The Romantic Ideology he has come (by 1992) to accept an important objection. "The charge is that The Romantic Ideology at times simply replaces Wellek's tripartite structural representation with a dialectical view that is, finally, no less conceptual, for all its appeal to dynamic forms" (241). 3

Now, if McGann did not succeed in redefining Romanticism (or to work himself free of all conceptualisations of it) in that book, the question arises whether he has managed to do so 
since then? All the more so, since he claims that it was "to study why Byron who, for nearly a hundred years ... defined ... the meaning of Romanticism, had all but disappeared from the most serious forms of academic and professional attention" that induced him to start research on Byron originally (1). As often with McGann, this is just as much a practical issue as a theoretical one, since he edited The New Oxford Book of Romantic Period Verse (1993), and one of the essays touches upon his principles of selection. This is the way McGann describes the concept of the anthology that differentiates it from "Wellek's synthetic view of Romanticism." "First, it includes a good deal of poetry - some of it, like Crabbe's, among the best writing of the period - that is not Romantic. Second, it gives a prominent place to work that was famous in its time but that later fell from sight. ${ }^{4}$ Third, it represents two key transitional moments of the Romantic period - the decades (roughly speaking of the 1790 s and the 1820s) - more completely, and hence more problematically, than is done in narrative literary histories or anthologies of the period" (246-7).

In his introduction to the New Oxford Book he states that "[w]hen we speak of romantic writing, even within its periodic context, we refer to a body of extremely diverse materials. The historic impossibility of defining the term 'romantic' reflects its diversity" (xx). He speaks, instead, of various parallel, competing traditions very much alive in the age, but largely forgotten since. Such "critical point[s] of departure" include "the so-called Della Cruscan poetry of sentiment" (The Florance Miscellany, 1785), Sir William Jones' translations from the Vedic hymns (1785), Burns' influential Poems, Chiefly in the Scottish Dialect (1786).

The overall aim of the method is very clear. McGann attempts to diminish (as much as possible) the narrative aspect in the anthology, to avoid making a distinction between central and peripheral works, or to present the period in terms of rise and fall. "One gets a very different view from a tighter focus" (247) he claims, and argues that it is the critic's task "to display the constructed and non-natural status of historical information" (244). This explains more or less his unwillingness to construct a new definition of Romanticism. "We do not, after all, have to think in such terms" (241) this seems to be his final word on the subject.

In opposition to the largely familiar theoretical and methodological 
statements of the collection, there are a number of novelties in the essays. The most important among these is the attention they give to Byron's lyric poetry. Both Fiery Dust and Don Juan in Context focused on Byron's major narratives (although the first did contain analyses of pieces from nearly all the genres of Byron's poetry). Here, however, he seems to reject the traditional view that Byron' best work does not belong to the lyrical mode. He argues that the reason these pieces receive too little attention is, on the one hand, a too rigid framework of definition (he refers repeatedly to M. H. Abrams's "Structure and Style in the Greater Romantic Lyric," 1965), and on the other, because they rely on the forgotten tradition of Della Cruscan poetry. 5 This legacy, present in the writings of all major Romantics, can be characterised as a "distinctly urban project ... committed to extreme displays of stylistic artifice" (Romantic Period Verse, $\mathrm{xx}$ ), a love poetry based on the "idea that true love had to involve a total intensity of the total person mind, heart and (here was the sticking point) body," and which carries, thus, "the stylistic index of ... selfconscious fleshliness" (Byron and Romanticism, 57-8).

Another novelty is in McGann's general attitude. After the distinctly combatant position of some of his earlier writings, it is very pleasant to hear him speak in a much more relaxed tone of voice. He refers very openly to his New Critical upbringing and his adherence (to a certain extent) to the practice of close reading. He also acknowledges the (historical) importance of deconstruction ("all those deconstructive moves [of Paul de Man] on the text seem to me exactly the right thing to have made at that time," 258). ${ }^{6}$ He even goes as far as to claim at one point that "I regard all readings of poetry as correct" (292). This, however, must not be taken at face value. This statement amounts to saying that every reaction to poetry contains useful insights for the historically minded critic, who is the only recipient who can formulate an opinion in a truly reflexive and critical vein. What is more significant about McGann's less rigid theoretical position is the fundamental importance he attributes to poetry. In his view, the world we are living in is a world of simulacra, in which poetry is one of the few remaining sources of "immediate experience" (263). Consequently, for all his concern about poetry's facticities, he is not very likely to dissolve poetry in other forms of discourse, or simply among historical sources (he applies the traditional formalist definition: "poetry 
is language calling attention to itself," 261).

The most problematic issue is, obviously, McGann's relation to the notion of Romanticism. The problem appears largely tactical in nature. If one maintains that the classical definitions of Romanticism (Wellek's or Abrams's definitions) are wrong because they leave no room for a major Romantic poet, i.e. Byron, then one simply has to give a new meaning to the word, which can endorse both, say, Wordsworth and Byron. The other way is to abandon the usage of the term altogether. However, McGann does neither of these. The consequence is that his arguments and his terminology remain dependent on the "synthetic" views of Romanticism. McGann's has to admit that "Byron's relation to Romanticism is secondary and critical," which is, after all, exactly what M. H. Abrams said more than thirty years ago: "Byron I omit altogether; not because I think him a lesser poet than the others but because in his greatest work he speaks with an ironic counter-voice and deliberately opens a satirical perspective on the vatic stance of his Romantic contemporaries" (Natural Supernaturalism, 13).

A word has to be said about McGann's individual style of writing. The reader is likely to be struck by the scale of voices in which he can speak, even within a single paper, some of which are written in a dialogic form. The experimental forms can probably be attributed to his cautiousness about formulating rigid "scientific" definitions, and even to what he calls the immediacy of the experience of poetry. More light seems to be shed on the question, however, if his style is regarded as Byronic in itself (according to McGann's own descriptions of the Byronic), and as a reflection of his "essaying a Byronic, oppositional life" (290). In fact, the composition of the whole book can be characterised by a dialectic of sincerity and mask-plays. It begins and ends by pieces of a very intimate tone of voice: a general introduction reflecting on his own carrier, an interview, and a dialogue. But even within the seemingly more conventional articles, his style varies between that of the meticulous philologist and the pamphlet-writer. $\mathrm{He}$ explicitly reflects on his work as a series of role-plays, and indeed he proves that he can speak from the position of a respectable lecturer, but also from that of someone making jokes (even practical jokes) in a pub. The cover illustration of Byron and Romanticism is given as "anonymous (previously attributed to Géricault), Portrait of a Man (also known as 
Portrait of Lord Byron)," not much more can be said about the identity of the book's "speaker" or, as a matter of fact, about its hero.

By way of summary, it might be fair to say that if McGann's general theoretical or methodological statements can be debated (are meant for debate); one thing, however, is beyond doubt: his masterful knowledge of the philological and textological facts he is working with. He claims (in 2001) to have collected the essays as an antidote to "the relative neglect of the minute particulars of literary works as they are literary and aesthetic. The New Critical origins of much of my work, which has been noticed and sometimes attacked throughout our New Historicist years, may perhaps gain a new salience at this moment" (289). It certainly may.

\section{Bálint Gárdos}

\section{Notes}

1. Byron: Hints from Horace, 100.

2. "Editing Byron brought a nearly complete deconstruction of my thinking about literature, art, and culture generally.... [T] he editorial work threw me down to where all our literary ladders start: in the concrete circumstances of those material and ideological histories that engage the production and transmission of 'texts' " (3).

3. The charge was formulated first by Marjorie Levinson (a student of McGann), but similar arguments have been brought up by Clifford Siskin and Frances Ferguson as well.

4. The most important among these seems the inclusion of women authors such as F. D. Hemans, or L. Barbauld.

5. The topic of a monograph by McGann, The Poetics of Sensibility (1996).

6 . He claims that the reason of the "return of the Byronic repressed" has been, apart from the editorial scholarship, the post-modern turn "with its Derridean concern for free play and instability and its Foucaultian pressure to recover salient but neglected historicalities" (238). 